\title{
GROWTH AND NUTRITIONAL STATUS OF BRAZILIAN WOOD SPECIES CEDRELLA FISSILIS AND ANADENANTHERA PEREGRINA IN BAUXITE SPOIL IN RESPONSE TO ARBUSCULAR MYCORRHIZAL INOCULATION AND SUBSTRATE AMENDMENT
}

\author{
Marcos Rogério Tótola*; Arnaldo Chaer Borges \\ Departamento de Microbiologia, Universidade Federal de Viçosa, Viçosa, MG, Brasil \\ Submitted: December 03, 1999; Returned to authors for corrections: August 28, 2000; Approved: November 07, 2000
}

\begin{abstract}
The growth of Cedrella fissilis Vell. (Cedro Rosa) and of Anadenanthera peregrina Benth (Angico Vermelho) in bauxite spoil was studied to evaluate their response to substrate amendment or to inoculation with arbuscular mycorrhizal fungi (AMF). The plants were grown in bauxite spoil, topsoil or spoil amended with either topsoil or compost, and inoculated with the AMF Acaulospora scrobiculata, Gigaspora margarita or Glomus etunicatum. Root colonization was highly dependent on the interaction plant-fungus-substrate. In C. fissilis, root colonization by Gigaspora margarita dropped from $75 \%$ in bauxite spoil to only $4 \%$ in topsoil. Contrarily, root colonization of A. peregrina by the same fungus increased from $48 \%$ in spoil to $60 \%$ in topsoil. Root colonization of $C$. fissilis in topsoil was lower than in the three other substrates. The opposite was observed for A. peregrina. Inoculation of the plants with Acaulospora scrobiculata or Glomus etunicatum was very effective in promoting plant growth. Plants of both $C$. fissilis and A. peregrina did not respond to amendments of bauxite spoil unless they were mycorrhizal. Also, a preferential partitioning of photosynthates to the shoots of A. peregrina inoculated with G. etunicatum or A. scrobiculata, and of $C$. fissilis inoculated with any of the three species of AMF was observed. $C$. fissilis showed a greater response to mycorrhizal inoculation than A. peregrina. The mean mycorrhizal efficiency (ME) for dry matter production by $C$. fissilis was $1,847 \%$ for A. scrobiculata, 1,922\% for G. etunicatum, and 119\% for G. margarita. In A. peregrina, the ME was $249 \%$ for A. scrobiculata, $540 \%$ for G. etunicatum, and 50\% for G. margarita. The effect of mycorrhizal inoculation on plant growth seems to be related in part to an enhanced phosphorus absorption by inoculated plants. Moreover, the efficiency with which the absorbed nutrients were used to produce plant biomass was much greater in plants inoculated with A. scrobiculata or G. etunicatum.
\end{abstract}

Key words: rehabilitation; mining; Glomus; Acaulospora; Gigaspora

\section{INTRODUCTION}

Mining activities generate a variety of wastes whose presence in soils has adverse characteristics for plant growth, such as low water infiltration rates, rough surfaces, poor aeration, high levels of heavy metals, low fertility, salinity and extremes of $\mathrm{pH}(15,21)$. These attributes may have deleterious effects on plant and soil microbial communities and must be ameliorated to ensure successful land reclamation. Under these conditions, mycorrhizal associations can improve plant establishment and growth $(8,13,14,20,25,29,31,36)$.

Reintroduction of arbuscular mycorrhizal fungi (AMF) in sites whose populations of indigenous endophytes have been reduced by mining activities or other disturbs may be critical to plant community restoration $(12,31,35,38)$. Furthermore, the selection and inoculation of plants with more efficient strains of AMF may improve plant growth $(1,8,14,22,24,36)$. Although native AMF are potential candidates for inoculation programs,

\footnotetext{
* Corresponding author. Mailing address: Departamento de Microbiologia, Universidade Federal de Viçosa, CEP 36571-000, Viçosa, MG, Brasil. Fax: (+5531) 899-2573. E-mail: totola@mail.ufv.br
} 
these fungi may not be adapted to the new conditions resulting from mining activities $(27,30,32,34)$.

Native plant species from mined sites that are to be rehabilitated have been used in order to regenerate plant communities found before anthropogenic interference. Wood species occurring in soils near bauxite deposits in Minas Gerais, Brazil, have been classified according to their presence or absence in soils containing subsurface bauxite ore. Anadenanthera peregrina occurs in the presence of bauxite ore. On the other hand, Cedrella fissilis is present only in sites surrounding bauxite beds, according to the botanical survey carried by Alcan Alumínio do Brasil SA (unpublished data).

Where it is possible, the mining sites to be revegetated must be covered with a layer of topsoil, to improve chemical and physical properties of the substrate and to reinoculate the area with seeds of native plant species and soil microorganisms. The use of compost also contributes to plant growth, when topsoil is not available.

Despite the number of works showing the contribution of mycorrhizal inoculation and substrate amendment for rehabilitation of mining sites, little work has been done with native plants of Brazil, including valuable wood species with differing exigencies for soil fertility. A. peregrina is a species commonly used in the revegetation of degraded sites, due to its good adaptation to soils of low fertility and poor physical characteristics. On the other hand, $C$. fissilis is a valuable timber wood, much similar to the australian Red Cedar, being much more exigent on soil fertility and physical properties than $A$. peregrina.

This work reports the response of these two species to the amendment of bauxite spoil with topsoil or compost and to mycorrhizal inoculation, and shows that it is imperative to inoculate $C$. fissilis and $A$. peregrina to attain proper growth in this substrate.

\section{MATERIALS AND METHODS}

The experiment was conducted as a randomized block design, with a factorial array of 16 treatments for both Cedrela fissilis and Anadenanthera peregrina. There were four substrates (spoil, topsoil, spoil plus compost, spoil plus topsoil) and four types of mycorrhizal inoculation (no inoculation or inoculation with either Acaulospora scrobiculata, Gigaspora margarita or Glomus etunicatum). Each treatment was replicated five times for a total of 80 plants for each plant species.

Bauxite spoil and topsoil were collected at Mariana, Minas Gerais. The samples were air-dried, passed through a $5 \mathrm{~mm}$ sieve and chemically characterized (Table 1). The spoil was amended with $5 \%(\mathrm{w} / \mathrm{w})$ compost (SC), made of manure and molasses grass, or with $43 \%(\mathrm{w} / \mathrm{w})$ topsoil collected under a 9 year-old eucalyptus plantation (ST). Topsoil (T) or mine spoil (S) were also used in the original form as substrates for plant growth. The level of nutrients in the upper layer (see below) was corrected to $1.2 \mathrm{Cmol}_{\mathrm{c}} \mathrm{dm}^{-3} \mathrm{Ca}^{2+}, 0.3 \mathrm{Cmol}_{\mathrm{c}} \mathrm{dm}^{-3} \mathrm{Mg}^{2+}$, $100 \mathrm{mg} \mathrm{dm}^{-3} \mathrm{~K}$, and $10 \mathrm{mg} \mathrm{dm}^{-3} \mathrm{P}$. Substrates were sterilized (100 $\mathrm{cm}^{3} \mathrm{~m}^{-3}$ methyl bromide) and incubated for 20 days. A $1,200 \mathrm{~cm}^{3}$ layer of one of the substrates described above (fertilized spoil, spoil plus topsoil, spoil plus compost or topsoil) was placed over a $1,000 \mathrm{~cm}^{3}$ layer of unfertilized and unamended mine spoil in $2,200 \mathrm{~cm}^{3}$ plastic pots.

Seedlings of $A$. peregrina and $C$. fissilis were obtained from disinfected seeds germinated in autoclaved sand and

Table 1. Chemical analyses of the substrates spoil (S), topsoil (T), spoil amended with topsoil (ST) and spoil amended with compost (C)

\begin{tabular}{|c|c|c|c|c|}
\hline \multirow[t]{2}{*}{ Characteristics } & \multicolumn{4}{|c|}{ Substrate } \\
\hline & Spoil & Topsoil & Spoil + Topsoil ${ }^{11}$ & Spoil + Compost ${ }^{12}$ \\
\hline pHH & 5.7 & 6.1 & 6.4 & 5.8 \\
\hline $\mathrm{Ca}^{2+}\left(\mathrm{Cmol} / \mathrm{dm}^{3}\right)^{13}$ & 1.1 & 2.0 & 1.0 & 2.8 \\
\hline $\mathrm{Mg}^{2+}\left(\mathrm{Cmol} / \mathrm{dm}^{3}\right)^{1 / 3}$ & 0.2 & 0.2 & 0.2 & 0.8 \\
\hline $\mathrm{Al}^{3+}\left(\mathrm{Cmol} / \mathrm{dm}^{3}\right)^{13}$ & 0.0 & 0.0 & 0.0 & 0.0 \\
\hline $\mathrm{H}+\mathrm{Al}\left(\mathrm{Cmol} / \mathrm{dm}^{3}\right)^{14}$ & 0.3 & 7.2 & 5.3 & 1.2 \\
\hline $\mathrm{K}\left(\mathrm{mg} / \mathrm{dm}^{3}\right)^{15}$ & 222 & 173 & 142 & 939 \\
\hline $\mathrm{P}\left(\mathrm{mg} / \mathrm{dm}^{3}\right)^{15}$ & 10.8 & 12.8 & 7.0 & 13.9 \\
\hline
\end{tabular}

\footnotetext{
${ }^{/ 1}$ Bauxite spoil amended with $43 \%$ topsoil

${ }^{12}$ Bauxite spoil amended with $5 \%$ compost

${ }^{13}$ Extracted by $\mathrm{KCl} 1 \mathrm{~mol} \mathrm{~L}^{-1}$

${ }^{14}$ Extracted by CaOAc $1 \mathrm{~mol} \mathrm{~L}^{-1}, \mathrm{pH} 7.0$

${ }^{15}$ Extracted by Mehlich-1
} 
grown in a growth chamber for 30 days. Endomycorrhizal inoculum was obtained from separate pot cultures. Spore numbers in the inoculum were determined by the wet sieving method (16). Inoculation was done at the time of transplanting the seedlings, adding $10 \mathrm{~g}$ of soil-root inoculum (1400 spores) around the roots. Control plants received a spore-free leachate of mixed inoculum to equalize for other microflora introduced with the inoculum soil. The experiment was conducted with one plant per pot.

Pots were maintained in a green house at around $70 \%$ water holding capacity throughout the experiment by frequent weighing. The growth conditions were: $35 / 25^{\circ} \mathrm{C}$ maximum/ minimum temperatures; $93 / 75 \%$ maximum/minimum relative humidities; $16 \mathrm{~h}$ photoperiod and maximum light intensity of $950 \mu \mathrm{mol}$ photons $\mathrm{m}^{-2} \mathrm{~s}^{-1}$. At 20 and 65 days after transplanting, plants received micronutrients solution ( $1 / 4$ strength) (7) and $20 \mathrm{mg} \mathrm{N}-\mathrm{NH}_{4} \mathrm{NO}_{3}$.

Plants were harvested 135 days after transplanting to pots. Roots were washed free of soil, and a root subsample of about $1 \mathrm{~g}$ was taken randomly to access mycorrhizal colonization (17). The remaining roots and the shoots were dried at $75^{\circ} \mathrm{C}$, digested in nitric-percloric mixture and analyzed for macronutrients. Phosphorus was analyzed by the ammonium phosphomolybdate method (11). Calcium and magnesium were analyzed by atomic absorption and potassium by flame photometry.

Mycorrhizal efficiency based on dry matter production was calculated by the formula:

$\mathrm{ME}=[(\mathrm{M}-\mathrm{NM}) / \mathrm{NM}] \mathrm{X} 100$

where $\mathrm{M}$ and $\mathrm{NM}$ represent the dry matter production by mycorrhizal and nonmycorrhizal plants (35).

Nutrient utilization index (UI) was determined by the formula: $\mathrm{UI}=(\mathrm{DM})^{2} / \mathrm{X}$ where DM is dry matter and $\mathrm{X}$ is the amount of absorbed nutrient in miligrams (33).

The data were compared by Tukey's Test following a complete ANOVA.

\section{RESULTS}

Root colonization in $C$. fissilis did not differ between the 3 arbuscular mycorrhizal fungi (AMF) in the spoil (S) or in the spoil plus compost (SC) (Table 2). Amendment of mine spoil with compost caused a decrease in root colonization by $G$. etunicatum. Nevertheless, this reduction in colonization was offset by a significant increase in soil fertility so it did not restrict plant growth (Table 3). On the other hand, topsoil amendment resulted in a significative reduction in root colonization by A. scrobiculata and G. margarita, but had no effect on root colonization by G. etunicatum (Table 2).

The pattern of root colonization in A. peregrina in response to changes in the substrate was different from that observed for $C$. fissilis (Table 2). There were no differences in root colonization in spoil, for all the three fungal species tested. However, root colonization of A. peregrina increased in topsoil (T), contrarily to that observed for $C$. fissilis. In spoil mixed with topsoil (ST), root colonization of $A$. peregrina by $G$. margarita and $G$. etunicatum was greater than in spoil. The effect of topsoil on root colonization was the opposite for the two plant species. While root colonization of $C$. fissilis in topsoil was lower than in the other substrates, the topsoil was the substrate more favorable for root colonization of A. peregrina (Table 2).

Plants of $C$. fissilis and $A$. peregrina inoculated with $A$. scrobiculata or $G$. etunicatum produced much more biomass than that inoculated with G. margarita or uninoculated (Table

Table 2. Percentage of root colonization by Acaulospora scrobiculata, Gigaspora margarita or Glomus etunicatum in Cedrella fissilis and Anadenanthera peregrina grown in bauxite spoil, topsoil, spoil+topsoil or spoil+compost

\begin{tabular}{llcccc}
\hline Host & Substrate & \multicolumn{5}{c}{ Fungus } \\
\hline \multirow{2}{*}{ C. fissilis } & & A. scrobiculata & G. margarita & G. etunicatum & Control \\
& Spoil & $61 \mathrm{Aa}$ & $75 \mathrm{Aa}$ & $75 \mathrm{Aa}$ & 0 \\
& Topsoil & $31 \mathrm{Bb}$ & $4 \mathrm{Cc}$ & $58 \mathrm{Aab}$ & 0 \\
& Spoil+Topsoil & $22 \mathrm{Cb}$ & $40 \mathrm{Bb}$ & $75 \mathrm{Aa}$ & 0 \\
& Spoil+Compost & $64 \mathrm{Aa}$ & $56 \mathrm{Aab}$ & $54 \mathrm{Ab}$ & 0 \\
\hline \multirow{2}{*}{. peregrina } & Spoil & $59 \mathrm{Abc}$ & $48 \mathrm{Ab}$ & $51 \mathrm{Ab}$ & 0 \\
& Topsoil & $78 \mathrm{Aa}$ & $60 \mathrm{Bab}$ & $81 \mathrm{Aa}$ & 0 \\
& Spoil+Topsoil & $52 \mathrm{Bc}$ & $70 \mathrm{Aa}$ & $76 \mathrm{Aa}$ & 0 \\
& Spoil+Compost & $69 \mathrm{Aab}$ & $25 \mathrm{Bc}$ & $68 \mathrm{Aa}$ & 0 \\
\hline
\end{tabular}

Values followed by same capital letter (row), and lowercase letter (column), do not differ at $\mathrm{P}<0.05$. 
3). The plants responded more favorably to mycorrhizal inoculation in spoil amended with compost. In this substrate, plants inoculated with G. margarita also produced more biomass than the uninoculated plants.

The root systems of both $C$. fissilis and A. peregrina did not growth beyond the superficial layers of fertilized or amended spoil. After achieving the lower layer of unfertilized spoil, the roots of the plants, in all treatments, stopped to growth.

The effect of mycorrhizal inoculation on plant growth was much more evident for $C$. fissilis, specially by examining the mycorrhizal efficiency for dry matter production (ME) (Tables 3 and 4).
Mycorrhizal efficiency for $C$. fissilis and A. peregrina was higher for plants inoculated with A. scrobiculata and $G$. etunicatum (Table 4). The mycorrhizal efficiencies for plants inoculated with G. margarita were low in substrates amended with topsoil. The inverse was observed for plants inoculated with either A. scrobiculata or G. etunicatum (Table 4). Amendment of spoil with topsoil increased the root colonization of $A$. peregrina by $G$. margarita, and decreased root colonization of $C$. fissilis by the same fungus. In substrates containing topsoil (T and ST), root colonization of $C$. fissilis was lower and of $A$. peregrina was higher than in the other substrates (Table 2).

Table 3. Dry matter production by Cedrella fissilis and Anadenanthera peregrina in response to inoculation with Acaulospora scrobiculata, Gigaspora margarita or Glomus etunicatum and to bauxite spoil amendment.

\begin{tabular}{llcccc}
\hline Host & Substrate & \multicolumn{5}{c}{ Fungus } \\
\hline \multirow{2}{*}{ C. fissilis } & A. scrobiculata & G. margarita & G. etunicatum & Control \\
& Spoil & $2.35 \mathrm{Ac}$ & $0.42 \mathrm{Bb}$ & $2.84 \mathrm{Ac}$ & $0.16 \mathrm{Ba}$ \\
& Topsoil & $3.56 \mathrm{Ab}$ & $0.16 \mathrm{Bb}$ & $3.08 \mathrm{Abc}$ & $0.15 \mathrm{Ba}$ \\
& Spoil+Topsoil & $3.76 \mathrm{Ab}$ & $0.16 \mathrm{Bb}$ & $3.71 \mathrm{Ab}$ & $0.13 \mathrm{Ba}$ \\
& Spoil+Compost & $6.43 \mathrm{Ba}$ & $2.35 \mathrm{Ca}$ & $8.58 \mathrm{Aa}$ & $0.61 \mathrm{Da}$ \\
\hline \multirow{2}{*}{ A. peregrina } & Spoil & $1.75 \mathrm{Bb}$ & $0.64 \mathrm{Cb}$ & $2.40 \mathrm{Ac}$ & $0.34 \mathrm{Ca}$ \\
& Topsoil & $2.22 \mathrm{Bb}$ & $0.60 \mathrm{Cb}$ & $3.93 \mathrm{Ab}$ & $0.67 \mathrm{Ca}$ \\
& Spoil+Topsoil & $0.72 \mathrm{Bc}$ & $0.64 \mathrm{Bb}$ & $3.45 \mathrm{Ab}$ & $0.68 \mathrm{Ba}$ \\
& Spoil+Compost & $2.80 \mathrm{Ba}$ & $1.43 \mathrm{Ca}$ & $4.78 \mathrm{Aa}$ & $0.63 \mathrm{Da}$ \\
\hline
\end{tabular}

Values followed by same capital letter (row), and lowercase letter (column), do not differ at $\mathrm{P}<0.05$.

Table 4. Mycorrhizal efficiency for dry matter production in plants of Cedrella fissilis and Anadenanthera peregrina in response to inoculation with Acaulospora scrobiculata, Gigaspora margarita or Glomus etunicatum and to bauxite spoil amendment.

\begin{tabular}{llcccc}
\hline Host & Substrate & \multicolumn{5}{c}{ Fungus } \\
\hline & & A. scrobiculata & G. margarita & G. etunicatum & Mean \\
\hline \multirow{4}{*}{ C. fissilis } & & & $(\%)$ & \\
& Spoil & $1369 \mathrm{Ab}$ & $162 \mathrm{Ba}$ & $1675 \mathrm{Ab}$ & \\
& Topsoil & $2273 \mathrm{Aa}$ & $7 \mathrm{Ba}$ & $1953 \mathrm{Aab}$ & \\
& Spoil+Topsoil & $2792 \mathrm{Aa}$ & $23 \mathrm{Ba}$ & $2754 \mathrm{Aa}$ & \\
& Spoil+Compost & $954 \mathrm{ABb}$ & $285 \mathrm{Ba}$ & $1307 \mathrm{Ab}$ & $370 \mathrm{a}$ \\
\multirow{2}{*}{ A. peregrina } & Spoil & 415 & 88 & 606 & $236 \mathrm{ab}$ \\
& Topsoil & 231 & -10 & 487 & $136 \mathrm{~b}$ \\
& Spoil+Topsoil & 6 & -6 & 407 & $377 \mathrm{a}$ \\
\hline Mean & Spoil+Compost & 344 & 127 & 659 & \\
\hline
\end{tabular}

Values followed by same capital letter (row), and lowercase letter (column), do not differ at $\mathrm{P}<0.05$. 
The effect of mycorrhizal inoculation on plant growth can be attributed in part to a improved phosphorus absorption by the inoculated plants (Table 5). It was not observed this effect for potassium, calcium or magnesium (data not shown). This, together with the low $\mathrm{P}$ concentration or $\mathrm{P}$ content (data not shown) of uninoculated plants or of plants inoculated with $G$. margarita, suggests that $\mathrm{P}$ was one of the main factors which limited the growth of these plants.

P concentration of $C$. fissilis inoculated with G. etunicatum grown in spoil was lower than that observed in spoil plus topsoil or in topsoil, contrary to the results obtained for A. peregrina (Table 5).

The highest effect of mycorrhizal infection on $\mathrm{P}$ content was observed for $C$. fissilis grown in spoil plus topsoil (data not shown). In this substrate, $\mathrm{P}$ content of plants inoculated with A. scrobiculata and G. etunicatum were, respectively, 127 and 84 times higher than that of the control plants. This enhanced $\mathrm{P}$ absorption may be related to the high mycorrhizal efficiency observed for these fungi (Table 4). On the contrary, the mycorrhizal efficiency for A. peregrina grown in soil plus topsoil was the lowest (Table 4), and this might have resulted from the lower ability of the mycorrhizal fungi to improve $\mathrm{P}$ absorption in this substrate (Table 5).

The root:shoot ratio of inoculated plants was lower than that of control plants, except for A. peregrina inoculated with G. margarita (Table 6). This indicates a preferential partitioning of the assimilated carbon to the shoots. The root:shoot ratios of C. fissilis grown in topsoil (T) or in spoil plus compost (SC) were lower than in spoil (S) and spoil plus topsoil (ST). For A. peregrina, the lowest root:shoot ratio was observed for plants grown in topsoil (Table 6). The root:shoot ratios of C. fissilis were about only $32 \%$ of that observed for $A$. peregrina. This reflects in a smaller absorption system to sustain plant growth, and must be one of the explanations for the higher dependency of $C$. fissilis on mycorrhizal inoculation (Table 4). Despite the lower root:shoot ratio of C. fissilis and of A. peregrina inoculated with AMF, a considerably higher dry matter production and nutrient content (data not shown) was obtained in relation to uninoculated plants. These results clearly demonstrate that mycorrhizal fungi efficiently substituted for the roots in the uptake of nutrients.

Plants of both species inoculated with G. etunicatum were more efficient in converting the absorbed nutrients to plant biomass (Tables 7 and 8). The utilization indexes (UI) of the nutrients by uninoculated plants were consistently low in all the substrates. The same was observed for dry matter production (Table 3 ). The effect of mycorrhizal inoculation on the UI of nutrients was higher for $C$. fissilis than for A. peregrina (Tables 7 and 8), as also observed for mycorrhizal efficiency (Table 4). These results are in accordance with the observed inability of $C$. fissilis to growth in soils of low fertility, and also suggest that this species is more dependent on mycorrhizal colonization in natural habitats than A. peregrina.

Table 5. Phosphorus concentration in shoots of Cedrella fissilis and Anadenanthera peregrina in response to inoculation with Acaulospora scrobiculata, Gigaspora margarita or Glomus etunicatum and to bauxite spoil amendment.

\begin{tabular}{|c|c|c|c|c|c|}
\hline Host & Substrate & & Fungus & & \\
\hline & & A. scrobiculata & G. margarita & G. etunicatum & Control \\
\hline & & & centration (mg & & \\
\hline \multirow[t]{4}{*}{ C. fissilis } & Spoil & $2,700 \mathrm{Aab}$ & $1,000 \mathrm{Bab}$ & $1,000 \mathrm{Bb}$ & 700Ba \\
\hline & Topsoil & $2,800 \mathrm{Aa}$ & $600 \mathrm{Cbc}$ & $1,500 \mathrm{Ba}$ & $600 \mathrm{Ca}$ \\
\hline & Spoil+Topsoil & $2,100 \mathrm{Ac}$ & $600 \mathrm{Cc}$ & $1,400 \mathrm{Ba}$ & $600 \mathrm{Ca}$ \\
\hline & Spoil+Compost & $2,400 \mathrm{Abc}$ & $1,200 \mathrm{Ba}$ & $1,500 \mathrm{Ba}$ & $700 \mathrm{Ca}$ \\
\hline \multirow[t]{4}{*}{ A. peregrina } & Spoil & $1,500 \mathrm{Ab}$ & 700Cab & $1,000 \mathrm{Bb}$ & $600 \mathrm{Cb}$ \\
\hline & Topsoil & $1,300 \mathrm{Abc}$ & $500 \mathrm{Cbc}$ & $800 \mathrm{Bbc}$ & $400 \mathrm{Cb}$ \\
\hline & Spoil+Topsoil & $1,100 \mathrm{Ac}$ & $400 \mathrm{Bc}$ & $500 \mathrm{Bc}$ & $400 \mathrm{Bb}$ \\
\hline & Spoil+Compost & $1,900 \mathrm{Aa}$ & $800 \mathrm{Ba}$ & $1,800 \mathrm{Aa}$ & $1,000 \mathrm{Ba}$ \\
\hline
\end{tabular}

Values followed by same capital letter (row), and lowercase letter (column), do not differ at $\mathrm{P}<0.05$. 
Table 6. Root:shoot ratio of Cedrella fissilis and Anadenanthera peregrina in response to inoculation with Acaulospora scrobiculata, Gigaspora margarita or Glomus etunicatum and to bauxite spoil amendment.

\begin{tabular}{|c|c|c|c|c|c|c|}
\hline \multirow[t]{2}{*}{ Host } & \multirow[t]{2}{*}{ Substrate } & \multicolumn{3}{|c|}{ Fungus } & \multirow[b]{2}{*}{ Control } & \multirow[b]{2}{*}{ Mean } \\
\hline & & A. scrobiculata & G. margarita & G. etunicatum & & \\
\hline & & \multicolumn{3}{|c|}{$\mathrm{P}$ concentration $\left(\mathrm{mg} \mathrm{Kg}^{-1}\right)$} & & \\
\hline \multirow[t]{4}{*}{ C. fissilis } & Spoil & 0.62 & 0.51 & 0.61 & 0.78 & $0.63 \mathrm{a}$ \\
\hline & Topsoil & 0.43 & 0.47 & 0.43 & 0.53 & $0.47 \mathrm{~b}$ \\
\hline & Spoil+Topsoil & 0.61 & 0.48 & 0.63 & 0.82 & $0.64 \mathrm{a}$ \\
\hline & Spoil+Compost & 0.47 & 0.40 & 0.30 & 0.44 & $0.40 \mathrm{~b}$ \\
\hline Mean & & $0.53 \mathrm{~B}$ & $0.47 \mathrm{~B}$ & $0.49 \mathrm{~B}$ & $0.64 \mathrm{~A}$ & \\
\hline \multirow[t]{4}{*}{ A. peregrina } & Spoil & 1.97 & 1.68 & 1.55 & 1.77 & $1.71 \mathrm{a}$ \\
\hline & Topsoil & 1.71 & 1.98 & 1.62 & 2.38 & $1.24 \mathrm{~b}$ \\
\hline & Spoil+Topsoil & 1.17 & 2.21 & 1.67 & 2.26 & $1.83 \mathrm{a}$ \\
\hline & Spoil+Compost & 0.91 & 1.90 & 0.94 & 1.21 & $1.92 \mathrm{a}$ \\
\hline Mean & & $1.44 \mathrm{~B}$ & $1.94 \mathrm{~A}$ & $1.45 \mathrm{~B}$ & $1.91 \mathrm{~A}$ & \\
\hline
\end{tabular}

Values followed by same capital letter (row), and lowercase letter (column), do not differ at $\mathrm{P}<0.05$.

Table 7. Utilization index of phosphorus and potassium in the shoots of Cedrella fissilis and Anadenanthera peregrina in response to inoculation with Acaulospora scrobiculata (As), Gigaspora margarita $(\mathrm{Gm})$ or Glomus etunicatum $(\mathrm{Ge})$ and to bauxite spoil amendment. S, T, ST and SC refers to spoil, topsoil, spoil+topsoil and spoil+compost.

\begin{tabular}{|c|c|c|c|c|c|c|c|c|c|}
\hline \multirow{3}{*}{ Host } & \multirow{3}{*}{ Substrate } & \multicolumn{3}{|c|}{ Phosphorus } & \multicolumn{5}{|c|}{ Potassium } \\
\hline & & \multicolumn{3}{|c|}{ Fungus } & \multicolumn{5}{|c|}{ Fungus } \\
\hline & & As & $\mathrm{Gm}$ & $\mathrm{Ge}$ & Control & As & $\mathrm{Gm}$ & $\mathrm{Ge}$ & Control \\
\hline & & & $m g$ dry $n$ & tter $)^{2} / \mathrm{mg}$ & & & g dry m & ter $)^{2} / \mathrm{mg}$ & \\
\hline \multirow[t]{4}{*}{ C. fissilis } & $S$ & $0.6 \mathrm{Bb}$ & $0.3 \mathrm{Bb}$ & $1.9 \mathrm{Ab}$ & $0.1 \mathrm{Ba}$ & $45 \mathrm{ABb}$ & $8 \mathrm{Ba}$ & $63 \mathrm{Ac}$ & $3 \mathrm{Ba}$ \\
\hline & $\mathrm{T}$ & $0.9 \mathrm{Bb}$ & $0.2 \mathrm{Cb}$ & $1.5 \mathrm{Ab}$ & $0.2 \mathrm{Ca}$ & $131 \mathrm{Aa}$ & $5 \mathrm{Ba}$ & $132 \mathrm{Ab}$ & $4 \mathrm{Ba}$ \\
\hline & ST & $1.1 \mathrm{Bb}$ & $0.2 \mathrm{Cb}$ & $1.8 \mathrm{Ab}$ & $0.1 \mathrm{Ca}$ & $121 \mathrm{Aa}$ & $4 \mathrm{Ba}$ & $121 \mathrm{Ab}$ & $3 \mathrm{Ba}$ \\
\hline & $\mathrm{SC}$ & $1.9 \mathrm{Ba}$ & $1.4 \mathrm{Ba}$ & 4.6Aa & $0.6 \mathrm{Ca}$ & $113 \mathrm{Ba}$ & $33 \mathrm{Ca}$ & $224 \mathrm{Aa}$ & $8 \mathrm{Ca}$ \\
\hline \multirow[t]{4}{*}{ A. peregrina } & $S$ & $0.4 \mathrm{Ba}$ & $0.4 \mathrm{Ba}$ & $1.0 \mathrm{Ab}$ & $0.2 \mathrm{Ba}$ & $38 \mathrm{Abb}$ & $14 \mathrm{Bab}$ & 78Ac & $8 \mathrm{Ba}$ \\
\hline & $\mathrm{T}$ & $0.6 \mathrm{Ba}$ & $0.5 \mathrm{Ba}$ & $2.1 \mathrm{Aa}$ & $0.5 \mathrm{Ba}$ & $129 \mathrm{Ba}$ & $49 \mathrm{Ca}$ & $270 \mathrm{Aa}$ & $40 \mathrm{Ca}$ \\
\hline & ST & $0.3 \mathrm{Ba}$ & $0.5 \mathrm{Ba}$ & $2.4 \mathrm{Aa}$ & $0.6 \mathrm{Ba}$ & $45 \mathrm{Bb}$ & $55 \mathrm{Ba}$ & $200 \mathrm{Ab}$ & $42 \mathrm{Ba}$ \\
\hline & $\mathrm{SC}$ & $0.8 \mathrm{BCa}$ & $0.8 \mathrm{BCa}$ & $1.4 \mathrm{Ab}$ & $0.3 \mathrm{Ca}$ & $57 \mathrm{Bb}$ & $24 \mathrm{Ba}$ & 114Ac & $11 \mathrm{Ba}$ \\
\hline
\end{tabular}

Values followed by same capital letter (row), and lowercase letter (column), do not differ at $\mathrm{P}<0.05$. 
Table 8. Utilization index of calcium and magnesium in the shoots of Cedrella fissilis and Anadenanthera peregrina in response to inoculation with Acaulospora scrobiculata (As), Gigaspora margarita (Gm) or Glomus etunicatum (Ge) and to bauxite spoil amendment. S, T, ST and SC refers to spoil, topsoil, spoil+topsoil and spoil+compost.

\begin{tabular}{|c|c|c|c|c|c|c|c|c|c|c|}
\hline & & \multicolumn{3}{|c|}{ Calcium } & \multicolumn{6}{|c|}{ Magnesium } \\
\hline \multirow[t]{2}{*}{ Host } & \multirow[t]{2}{*}{ Substrate } & \multicolumn{3}{|c|}{ Fungus } & \multicolumn{5}{|c|}{ Fungus } & \multirow[b]{2}{*}{ Mean } \\
\hline & & As & $\mathrm{Gm}$ & $\mathrm{Ge}$ & Control & As & $\mathrm{Gm}$ & $\mathrm{Ge}$ & Control & \\
\hline & & \multicolumn{3}{|c|}{$(\mathrm{mg} \text { dry matter })^{2} / \mathrm{mg} \mathrm{Ca}$} & \multicolumn{6}{|c|}{$(\mathrm{mg} \text { dry matter })^{2} / \mathrm{mg} \mathrm{Mg}$} \\
\hline \multirow[t]{4}{*}{ C. fissilis } & S & $253 \mathrm{Ab}$ & $23 \mathrm{Bb}$ & $262 \mathrm{Ab}$ & $8 \mathrm{Ba}$ & $721 \mathrm{Ab}$ & $101 \mathrm{Bb}$ & $918 \mathrm{Ab}$ & 30Ba & \\
\hline & $\mathrm{T}$ & $193 \mathrm{Ab}$ & $8 \mathrm{Bb}$ & $227 \mathrm{Ab}$ & $8 \mathrm{Ba}$ & $621 \mathrm{Ab}$ & $34 \mathrm{Bb}$ & $670 \mathrm{Abc}$ & $34 \mathrm{Ba}$ & \\
\hline & ST & $199 \mathrm{Ab}$ & $11 \mathrm{Bb}$ & $240 \mathrm{Ab}$ & $6 \mathrm{Ba}$ & $644 \mathrm{Ab}$ & $34 \mathrm{Bb}$ & $653 \mathrm{Ac}$ & $19 \mathrm{Ba}$ & \\
\hline & $\mathrm{SC}$ & $502 \mathrm{Ba}$ & $183 \mathrm{Ca}$ & 1169Aa & $39 \mathrm{Ca}$ & $1478 \mathrm{Ba}$ & $425 \mathrm{Ca}$ & $2495 \mathrm{Aa}$ & $119 \mathrm{Da}$ & \\
\hline \multirow[t]{4}{*}{ A. peregrina } & S & $89 \mathrm{Bb}$ & $26 \mathrm{Ca}$ & $156 \mathrm{Ab}$ & $15 \mathrm{Ca}$ & 579 & 213 & 1199 & 86 & $519 b$ \\
\hline & $\mathrm{T}$ & $97 \mathrm{Ab}$ & $25 \mathrm{Ba}$ & $150 \mathrm{Ab}$ & $22 \mathrm{Ba}$ & 919 & 293 & 1796 & 210 & $796 a$ \\
\hline & ST & $35 \mathrm{Bb}$ & $23 \mathrm{Ba}$ & $103 \mathrm{Ab}$ & $30 \mathrm{Ba}$ & 335 & 202 & 1373 & 203 & $528 \mathrm{~b}$ \\
\hline & $\mathrm{SC}$ & $226 \mathrm{Ba}$ & $66 \mathrm{Ca}$ & 390Aa & $33 \mathrm{Ca}$ & 763 & 239 & 1722 & 114 & $706 a b$ \\
\hline Mean & & & & & & 636B & $237 \mathrm{C}$ & $1522 \mathrm{~A}$ & $154 \mathrm{C}$ & \\
\hline
\end{tabular}

Values followed by same capital letter (row), and lowercase letter (column), do not differ at $\mathrm{P}<0.05$.

\section{DISCUSSION}

C. fissilis and A. peregrina are wood species utilized for revegetation of mining sites in Southeast Brazil. These species have different tolerances to the presence of bauxite ore in the soil and also different exigencies for soil fertility. Regardless of their importance, little is known about their association with arbuscular mycorrhizal fungi and their response to mine spoil amendment.

The inoculation of both $C$. fissilis and A. peregrina with AMF resulted in an overall highly positive effect on the plant growth, nutrient absorption and on the efficiency with which the absorbed nutrients were used to produce plant biomass.

The mycorrhizal fungi were very efficient in colonizing the roots of both species. Interestingly, amendment of spoil with topsoil increased the root colonization of $A$. peregrina by G. margarita, and decreased root colonization of $C$. fissilis by the same fungus. Also, in substrates containing topsoil ( $T$ and ST), root colonization of $C$. fissilis was lower and of $A$. peregrina was higher than in the other substrates (Table 2). The contrary was observed for mycorrhizal efficiency (Table 4). It is well known that fungistatic compounds present in the soil can inhibit root colonization, and that this effect can vary according to the plant-fungus combinations $(19,37)$. These complex responses are not well understood and reflect the subtle functioning of the mycorrhizal symbiosis in different plant-fungus-substrate interactions. Also, the results indicate the need for selecting amendments to be used in rehabilitation programs to attain maximum benefit from mycorrhizal inoculation.

A. scrobiculata and G. etunicatum were the most efficient fungi to promote plant growth for both $C$. fissilis and $A$. peregrina (Table 3 ), and this is in agreement with the higher ability of inoculated plants to absorb P. At this moment, it is not know if this effect was due to a greater exploitation of the substrate by the extramatrical hyphae of these two fungi or to a more favorable kinetic for $\mathrm{P}$ absorption, since the root colonization by G. etunicatum or A. scrobiculata did not differ greatly from that observed for $G$. margarita. The plant growth and $\mathrm{P}$ concentration in the shoots were not always correlated (Tables 3 and 5). P concentration in the shoots of $C$. fissilis grown in the spoil and inoculated with G. etunicatum did not differ from that of the control plants, although dry matter production by inoculated plants was 17.8 times higher. The same trend was observed for A. peregrina grown in spoil plus topsoil. These results show that in the study of mycorrhizal associations, other important effects of the association on the overall physiology of the host plant, like water relations, enhanced photosynthesis, hormonal effects, and others must also be considered $(2,3,4,5,6,18,39)$.

Amelioration of mine spoil with either topsoil or compost does not improve growth nor phosphorus absorption by both C. fissilis and A. peregrina, unless they are colonized by efficient AMF. The root system of these species is characterized by thick unbranched roots with few root hairs. Such characteristics render the root system less efficient for 
water and nutrient absorption, which has been associated with plants highly dependent on mycorrhizae $(9,10)$.

Mycorrhizal plants had a greater nutrient utilization index for dry matter production than control plants (Tables 7 and 8). Because of the low fertility of mine spoils (15, Table 1) and the poor capacity of mining sites to retain nutrients, a high efficiency in converting scarce resources to biomass may be an additional advantage for plants during the recolonization of these sites. This, together with the improved nutrient absorption, may explain the general success of mycorrhizae in rehabilitation programs $(8,12,14,22,23,31,36,38)$.

A. peregrina is considered to be a species fully adapted to low fertility soils, and it can be found growing in the presence of subsurface bauxite ore. On the other hand, $C$. fissilis has a greater requirement for nutrients than $A$. peregrina. This, together with its lower root:shoot ratio (Table 6), can be related to its higher response to AMF inoculation, its greater requirement for chemical and physical improvement of bauxite spoil and its poor adaptation to low fertility soils in natural habitats.

Plants of $C$. fissilis and A. peregrina grown in bauxite spoil showed a highly positive response to mycorrhizal inoculation, which resulted in higher dry matter production and improved nutrient uptake. The results demonstrated that mycorrhizal association plays a crucial role in promoting the growth of $C$. fissilis and $A$. peregrina, suggesting the importance of inoculation with AMF before outplanting these species to the field. This may be especially true for sites with low inoculum potential (35), such as mining sites $(2,26,28)$. Furthermore, the great variability among AMF species to promote plant growth shows the need for screening the best host-fungus-soil combination, if a successful rehabilitation of degraded sites is to be achieved.

\section{ACKNOWLEDGEMENTS}

The authors wish to thank Dr. Raymond S. Pacovsky for the critical review of the manuscript, to Mr. Maurício D. Costa for improving the English, and to CNPq (Conselho Nacional de Desenvolvimento Científico e Tecnológico-Brazil) for the financial support.

\section{RESUMO}

\section{Crescimento e estado nutricional das espécies Cedrella fissilis e Anadenanthera peregrina em estéril de mineração de bauxita em resposta à inoculação com fungos micorrízicos-arbusculares e à melhoria do substrato}

Estudou-se o crescimento de plantas de Cedrella fissilis Vell. (Cedro Rosa) e de Anadenanthera peregrina Benth
(Angico Vermelho) em estéril de mineração de bauxita e sua resposta à inoculação com fungos micorrízicos arbusculares (FMAs) ou à melhoria do substrato. As plantas foram cultivadas em estéril de mineração de bauxita, em solo de camada superficial, em estéril adicionado de solo de camada superficial ou de composto orgânico e inoculadas com os FMAs Acaulospora scrobiculata, Gigaspora margarita ou Glomus etunicatum. A colonização de C. fissilis por Gigaspora margarita foi reduzida de $75 \%$ em estéril de mineração de bauxita para apenas $4 \%$ em solo de camada superficial. Ao contrário, a colonização de $A$. peregrina pela mesma espécie fúngica aumentou de $48 \%$ no estéril para $60 \%$ em solo de camada superficial. A colonização radicular de $C$. fissilis em solo de camada superficial foi menor que nos outros três substratos testados, o oposto do resultado observado com $A$. peregrina. A inoculação de $C$. fissilis e A. peregrina com Acaulospora scrobiculata ou com Glomus etunicatum resultou em aumentos significativos na produção de biomassa vegetal. Plantas das duas espécies, quando não-inoculadas, não responderam às alterações das características do substrato de crescimento. Observou-se também uma partição preferencial de fotossintatos para a parte aérea de plantas de $A$. peregrina inoculadas com G. etunicatum ou com A. scrobiculata e de $C$. fissilis inoculadas com qualquer das três espécies de FMAs. C. fissilis respondeu mais significativamente à inoculação micorrízica que $A$. peregrina. A eficiência micorrízica média (EM) para a produção de matéria seca por C. fissilis foi de $1.847 \%$ para A. scrobiculata, $1.922 \%$ para G. etunicatum e $119 \%$ para G. margarita. Em A. peregrina, a EM foi de $249 \%$ para $A$. scrobiculata, $540 \%$ para $G$. etunicatum e de $50 \%$ para $G$. margarita. $\mathrm{O}$ efeito da inoculação sobre o crescimento das plantas parece ter resultado de um aumento na capacidade de absorção de fósforo. A eficiência com que os nutrientes absorvidos foram utilizados para produzir biomassa vegetal foi também significativamente maior em plantas inoculadas $\operatorname{com} A$. scrobiculata ou com G. etunicatum.

Palavras-chave: reabilitação; mineração; Glomus; Acaulospora; Gigaspora

\section{REFERENCES}

1. Abbott, L.K; Robson, A.D. The effect of VA Mycorrhizae on plant growth. In: Powell C Ll, Bagyaraj DJ (eds) VA Mycorrhiza. Boca Raton, CRC Press, 1984, p. 113-130.

2. Allen, E.B.; Allen, M.F. Natural re-establishment of vesicular arbuscular mycorrhizae following stripmine reclamation in Wyoming. J. Appl. Ecol. 17: 139-147, 1980.

3. Allen, M.F.; Boosalis, M.G. Effects of two species of VA mycorrhizal fungi on drought tolerance of winter wheat. New Phytol. 93: 67-76, 1983.

4. Allen, M.F.; Moore, T.S.; Christensen, M. Phytohormone changes in Bouteloua graassilis infected by vesicular arbuscular mycorrhizae. I. Cytokinin increases in the host plant. Can. J. Botany 58: 371-374, 1980. 
5. Allen, M.F.; Moore, T.S.; Christensen, M. Phytohormone changes in Bouteloua grassilis infected by vesicular arbuscular mycorrhizae. II. Altered levels of gibberellin-like substances and abscisic acid in the host plant. Can. J. Botany 60: 468-471, 1982.

6. Allen, M.F.; Smith, W.K.; Moore, T.S.; Christensen, M. Comparative water relations and photosynthesis of mycorrhizal and non-mycorrhizal Bouteloa grassilis (J.B.K.) Lag ex Steud. New Phytol. 88: 683-693, 1981.

7. Alvarez Venegas, V.H. Equilíbrio de formas disponíveis de fósforo e enxofre em dois latossolos de Minas Gerais. Viçosa, MG, 1974, 125p. (M.Sc. Thesis. Departamento de Solos. UFV).

8. Azcón, R.; Barea, J. M. Mycorrhizal dependency of a representative plant species in mediterranean shrublands (Lavandula spica $\mathrm{L}$.) as a key factor to its use for revegetation strategies in desertificationthreatened areas. Appl. Soil Ecol. 7: 83-92, 1997.

9. Baylis, G.T.S. Fungi, phosphorus and the evolution of plant roots. Search 3: 257-258, 1972.

10. Baylis, G.T.S. The magnolioid mycorrhiza and mycotrophy in root systems derived from it. In: Sanders, F.E.; Mosse, B.; Tinker, P.B. (eds.). Endomycorrhizas Academic Press, London, 1975, p. 373389.

11. Braga, J.M.; DeFelipo, B.V. Determinação espectrofotométrica de fósforo em extrato de solos e material vegetal. Rev. Ceres 21: 73-85, 1974.

12. Call, C.A.; McKELL, C.M. Vesicular-arbuscular mycorrhizae. A natural revegetation strategy for disposed processed oil shale. Recl. Reveg. Res. 1: 337-347, 1982.

13. Daft, M.J.; Hacskaylo, E. Arbuscular mycorrhizas in the anthracite and bituminous coal wastes of Pennsylvania. J. Appl. Ecol. 13: 523531, 1976

14. Estaún, V.; Savé, R.; Biel, C. AM inoculation as a biological tool to improve plant revegetation of a disturbed soil with Rosmarinus officinalis under semi-arid conditions. Appl. Soil Ecol. 6: 223-229, 1997

15. Fox, J.E.D. Rehabilitation of mined lands. For. Abst. 45: 565-595, 1984

16. Gerdemann, J.W.; Nicolson, T.H. Spores of mycorrhizal Endogone species extracted from soil by wet sieving and decanting. Trans. Br. Mycol. Soc. 46: 235-244, 1963

17. Giovanetti, M.D.; Mosse, B. An evaluation of techniques for measuring vesicular-arbuscular mycorrhizal infection in roots. New Phytol. 84: 489-500, 1980.

18. Huang, R.S.; Smith, W.K.; Yost, R.S. Influence of VA mycorrhiza on growth, water relations and leaf orientation in Leucaena leucocephala. New Phytol. 99: 229-244, 1985.

19. Koviacic, D.A.; St John, T.V.; Dyer, M.I. Lack of vesicular-arbuscular mycorrhizal inoculum in a ponderosa pine Pinus_ponderosa forest. Ecology 65: 1755-1759, 1984.

20. Lambert, D.H.; Cole Jr., H. Effects of mycorrhizae on establishment and performance of forage species in mine spoil. Agron. J. 72: 257260,1980

21. Lamont, B.B. Biophysical constraints to the rehabilitation of mine wastes. In: Fox, J.E.D. (ed.). Rehabilitation of mined lands in western Australia. South Bentley, Western Australia Institute of Technology, 1978 , p. $37-45$
22. Lumini, E.; Bosco, M.; Puppi, G.; Isopi, R.; Frattegiani, M.; Buresti, E.; Favilli, F. Field performance of Alnus cordata Loisel (Italian alder) inoculated with Frankia and VA-mycorrhizal strains in mine-spoil afforestation plots Soil Biol. Bioch. 26: 659-661, 1994.

23. Marx, D.H. Mycorrhizae and establishment of trees on strip-mined land. Ohio J. Sci. 75: 288-297, 1975.

24. Menge, J.A. Utilization of vesicular-arbuscular mycorrhizal fungi in agriculture. Can. J. Bot. 61: 1015-1024, 1983

25. Mehrotra, V.S. Use of revegetated coal mine spoil as source of arbuscular mycorrhizal inoculum for nursery inoculations. Current Science 71: 73-77, 1998.

26. Miller, R.M. Some occurrences of vesicular-arbuscular mycorrhizae in natural and disturbed ecosystems of the Red Desert. Can. J. Bot 57: 619-623, 1979.

27. Mosse, B.; Stribley, D.P.; Le Tacon, F. Ecology of mycorrhizae and mycorrhizal fungi. Adv. Microb. Ecol. 5: 137-210, 1981.

28. Mott, J.B.; Zuberer, D.A. Occurrence of vesicular-arbuscular mycorrhizae in mixed overburden mine spoil of Texas. Recl. Reveg. Res. 6: 145-156, 1987.

29. Noyd, R.K.; Pfleger, F.L.; Norland, M.R. Field responses to added organic matter, arbuscular mycorrhizal fungi, and fertilizer in reclamation of taconite iron ore tailing. Plant Soil 179: 89-97, 1996.

30. Pedersen, T.A.; Rogowski, A.S.; Pennock Jr., R. Comparison of morphological and chemical characteristics of some soils and minesoil. Recl. Rev. 1: 143-156, 1978

31. Pfleger, F.L.; Stewart, E.L.; Noyd, R.K. Role of VAM fungi in mine land revegetation. In: Pfleger FL and Linderman RG (eds.). Mycorrhizae and Plant Health. APS Press, St. Paul, Minnesota, 1994 p.47-81

32. Severson, R.C.; Gough, L.P. Rehabilitation materials from surface coal mines in the western USA. Recl. Reveg. Res. 2: 83-102, 1983.

33. Siddiqi, M.Y.; Glass, D.M. Utilization index: a modified approach to the estimation and comparison of nutrient utilization efficiency in plants. J. Plant Nut. 4: 289-302, 1981.

34. Smith, R.M.; Sobek, A.A. Physical and chemical properties of overburdens, spoils, wastes and new soils. In: Shaller, F.W.; Sutton, P. (eds.). Reclamation of drastically disturbed lands. Madison, Wisconsin, 1979, p.162-179.

35. Sylvia, D.M. Mycorrhizal symbioses. In: Sylvia, D.M.; Fuhrmann, J.J.; Hartel, P.G.; Zuberer, D.A. (eds.). Principles and applications of soil microbiology. Prentice Hall, New Jersey, 1999, p. 408-426.

36. Thorne, M.E.; Zamora, B.A.; Kennedy, A.C. Sewage sludge and mycorrhizal effects on secar bluebunch wheatgrass in mine spoil. $J$. Environ. Quality 27: 1228-1233, 1998.

37. Tobiessen, P.; Werner, M.B. Hardwood seedling survival under plantations of scotch pine and red pine in central New York. Ecology 61: $25-29,1980$

38. Trappe, J.M. Mycorrhizae and productivity of arid and semiarid rangelands. In: Manassah, J.T.; Briskey, E.J. (eds.). Advances in food producing systems for arid and semiarid lands. Academic Press, New York, 1981, p.581-599.

39. Trent, J.D.; Svejcar, T.J.; Christensen, S. Effects of fumigation on growth, photosynthesis, water relations and mycorrhizal development of winter wheat in the field. Can. J. Plant Sci. 69: 535-540, 1989. 